\title{
O BOCA A BOCA ON-LINE, UM NOVO SUPORTE E UMA NOVA ROUPAGEM
}

\section{Vânia Braz Oliveira'}

Resumo: A voz do consumidor contemporâneo se materializa nas redes sociais on-line por meio e suas expressões, aqui caracterizada pelas falas destes consumidores sendo essas capazes de avaliar uma marca e transmitir sua opinião pelas redes sociais on-line. Caracterizar o boca a boca on-line como um novo fluxo comunicacional entre consumidores, capazes de alterar a percepção da marca é o objetivo deste artigo. Com a pesquisa bibliográfica e documental evidenciamos que em uma sociedade relacional a voz do consumidor propagada

Palavras-chave: Boca-a-boca on-line; Consumidor contemporâneo; Sociedade em rede; Redes sociais online.

\footnotetext{
1 Universidade do Vale do Paraíba, Brasil. E-mail: vaniajor@univap.br.
} 